deeply at variance with the facts of Samoan ethnography and history [p.109].

However, the data sources and evidence presented by Mead and Freeman are quite different. Mead, then 23, worked with adolescent and pre-adolescent girls in three villages in Manu'a. In an appendix she presented data sheets for the analysis of girls' age, family and social position, and behaviour. She described adolescence as the best period of a woman's life, without stress or conflict, preoccupied with sex and lovemaking. Mead contrasted the gentle and carefree adolescence of Samoans with the educational and social pressures upon American youth, urging America to be less demanding of its young.

Freeman goes to great lengths to disprove Mead's characterization of Samoan adolescence. To establish that Samoan youths have a similar pattern of violence to that in other countries, he cites court records of Western Samoa, for 1967, which show that males in the age-group 14-20 constitute a high proportion of first offenders. It is as though observations of teenagers in a village such as Lower Slaughter in 1925 are disproved by Birmingham police records for 1967. Freeman says,

Mead, then, was at error in her depiction of the nature of adolescence in Samoa, just as she was

. in her portrayal of other crucial aspects of Samoan life. This being so, her assertion in Coming of Age in Samoa of the absolute sovereignty of culture over biology, on the basis of these erroneous depictions, is clearly invalid, and her much-bruited "negative instance" is seen to have been no negative instance at all. In other words, Mead's presentation of Samoa as proving the insignificance of biology in the etiology of adolescent behavior is revealed as a false case [p.268].

Freeman's critique includes the complaint that Mead never returned to Samoa, nor revised her books on the basis of later studies. In response to this, Mead speaks for herself in the preface to the 1973 edition of Coming of Age in Samoa:

Some young critics have even asked me when I am going to revise this book, and look unbelieving and angry when I say that to revise it would be impossible. It must remain, as all anthropological works must remain, exactly as it was written, true to what I saw in Samoa, and of what I was able to convey of what I saw. True to the state of our knowledge of human behavior as it was in the mid-1920s, true to our hopes and fears for the future of the world $[\mathrm{p}, \mathrm{x}]$.

Further, Mead clearly acknowledged the importance of the work of others, including Freeman, in her conclusion to the reissued Social Organization of Manu'a in 1969:

Then, in 1965, I met Derek Freeman for the first time, and he challenged my material on the very mild Manu'an reactions I had reported on the

*The "negative instance" is defined by Freeman as Boas's view of scientific method in which a single negative case invalidates a hypothesis. In fact, Freeman dedicates his book to Karl Popper because of Popper's work on scientific method. subject of virginity. He cited intense feeling about virginity on the part of mothers of girls, and extreme preoccupation with the theft of girls in other villages on the part of young men in western Samoa. In thinking this over, I realized for the first time that the whole of the rivalry between the young men or the chiefs of different villages, could be expressed in the hope of one group that they could do irreparable, asymmetrical damage to the other group. . . Translated into terms of behavior, it accounts for the continuous wariness and touchiness which Samoans display in several contexts ever alert lest something one would enjoy doing to others be done to oneself

We need much more detailed material on early childhood, material which hopefully Derek Freeman's current fieldwork will provide [p.227].

The very nature of ethnographic field work, as a local study by a lone anthropologist, raises questions about reliability and generalization. The field worker pursues particular subjects and problems, chooses a community, works closely with only some members of that community, and publishes observations and conclusions based upon the fieldwork and the information available from other sources. Subsequent research among the same people - in this case an island group with a population of over $150,000-$ is likely to find differences attributable to local conditions, historical changes, and interpretation or emphasis. Certainly ambiva-

lences and contradictions characterize every society. Conflicting findings are sometimes taken as evidence that anthropological research is both subjective and unreliable. And while Freeman presents much evidence to contradict Mead's statements, he cannot claim to have reproduced her conditions of field work with adolescent girls in Manu'a in 1925. His contention that she was innocently duped and misled by village girls is unwarranted.

Why, one wonders, has not Freeman written a new book on Samoa which incorporates the results of his researches, rather than a series of chapters devoted to Mead's "errors"? He amply demonstrates his ability to describe the social, political and rank system of Samoa in a way that summarizes his research and that of many other scholars into a clear and consistent statement. One can only surmise that his was personal preference for criticism over construction. By this choice, he has prevented anthropologists from evaluating the potential of his biological explanation of Samoan behaviour. Mead's work will continue to reflect its time and place, but Freeman has yet to demonstrate the correctness of his position.

Paula Brown Glick is Professor of Anthro pology at the State University of New York, Stony Brook. She is author of Highland Peoples of New Guinea (Cambridge University Press, 1978).

\section{Little room for the anthropologist}

\section{Mary Douglas}

\section{Margaret Mead: A Voice for the}

Century.

By Robert Cassidy.

Universe Books: 1982. Pp.176. \$12.50.

MARGARET Mead, born into an academic family in Philadelphia in 1901, died internationally famous and loaded with honours in 1978. Her remarkable life deserves to be recorded and reflected upon. She was an anthropologist, a teacher, a humanitarian, a popular writer, a media star and a lay preacher. Her record defies classification but it invites a more reflective treatment than is here provided by Robert Cassidy. His book suffers the usual limitations of hagiography, strong in praise of the deceased and weak in dealing with the enigmas and problems of a person living in a particular place and time. We are left with hints - apparently fellow ethnologists accorded her only "grudging admiration" and her success was definitely in the larger community, "grandmother to America", "citizen of the world" or "voice for the century".

Her graduate work was in the University of Columbia, with Franz Boas and Ruth Benedict. Boas was building up a new science of anthropology, specially focused on the relationship between the invidual and culture and on methods of assessing that relationship. Cassidy's account of how Boas set the theoretical problems of her fieldwork project does not quite ring true. That towering scholar, geologist, physicist, organizer of great Arctic and north American expeditions, apparently first drew her attention to the cultural variation in sexual mores. He is said to have asked her whether adolescent troubles were peculiar to Western culture - how did young girls react to the constraints of custom, was it true that primitive girls were excessively bashful, did they develop crushes and other forms of romantic love? It sounds more like what his student told him she intended to study and clearly, even at that youthful age, she was not one to be easily diverted from her purposes.

In 1925 she went to Samoa, chosen by her supervisors as a place where she could be safe under the watchful eye of the United States Department of the Navy. Mary Slessor and Mary Kingsley, much earlier travellers in West Africa, and Edith Durham, travelling in the feuding Balkans, would not have made much of the dangers she faced in the South Pacific. On her return she wrote Coming of Age in Samoa published in 1928, which overnight became a bestseller. Perhaps the grudgingness of colleagues' admiration stemmed from this instant popular success, or perhaps it confirmed a wilful independence and sense 


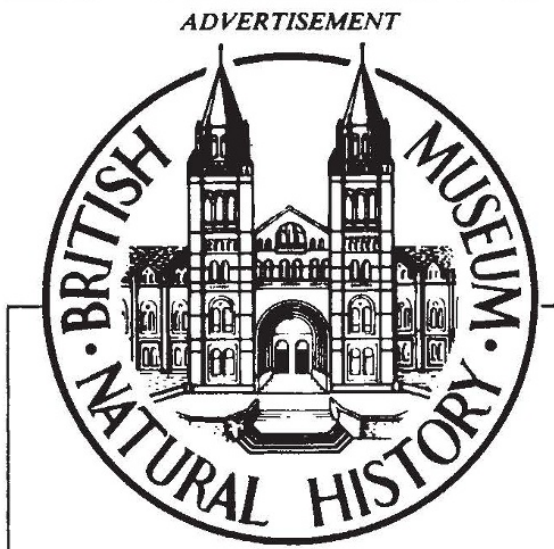

Blue butterflies of the Lycaenopsis-group By J.N. Eliot \& A. Kawazoé

A detailed taxonomic study and revision.

Unique specimens and the rarer species

illustrated in colour. Line drawings, keys and descriptions for identification to subspecific level. 1983. 296pp. 6 plates colour, $12 \mathrm{~b} / \mathrm{w}$. 560 line figures.

0565008609 Hardback.

Until June 1. $£ 25.00$

Afterwards $£ 28.00$

A directory of natural history and related societies in

\section{Britain and Ireland}

Compiled and edited by Audrey Meenan

Addresses, aims, amenities, meetings etc of

local, national, school and college societies

listed from $A-Z$, geographically and by

subject. "Natural History" being here

interpreted in its widest sense.

1983,407pp. 0565008595

Hardback $£ 15.00$

\section{A checklist of the helminth parasites of marsupials and monotremes}

By E.A. Harris

Brings together the published literature on the nematodes, trematodes, cestodes and acanthocephalans recorded from marsupials and monotremes. Microfiche, 2 fiche in introductory folder. $0565008749 £ 6.00$

\section{List of British vascular plants}

Prepared by J.E. Dandy

for the British Museum (Natural History) and the Botanical Society of the British Isles.

' 1 corporating the London catalogue of British plants. First printed 1958 this important work has been out of print for some years. it has now been reprinted to meet continuing demand, $\mathrm{v}+176 \mathrm{pp}$. 0565004492 Hardback $£ 5.00$

\section{Flora Zambesiaca.}

Vol. VII part 1.

Families Crassulaceae, Valerianaceae. Dipsacaceae; then Campanulaceae Loganicaeae.

Edited by E. Launer.

The latest published in this ongoing series by the Managing Committee of Flora

Zambesiaca. 1983 394pp.89 line drawings, colour frontispiece. 0950768200 . Paperback $£ 23.50$.

\section{Guernsey's earliest flora}

By D. McClintock

An account of the plants of the Guernsey countryside circa 1790. Based on the work of Joshua Gosselin (1739-1812). 210pp, frontispiece, 7 figures. A Ray Society publication No.155,0903874 172 Hardback $£ 14.00$

Publications Sales, British Museum (Natura History), Cromwell Road, London SW7 5BD of power in the young scholar. She was offered a post of Assistant Curator in the American Museum of Natural History in 1926 and declared that once she saw through the windows of her attic room in that august establishment she would never move out.

Was it really this resolution that prevented her from accepting any other academic appointment, as Cassidy implies? In 1954 she was made Adjunct Professor in the Anthropology Department at Columbia but never improved upon that part-time peripheral post until 1968 , when Fordham University asked the now ageing superstar to develop their department of anthropology. There are others who have done great research from museums, and others who have been delayed from holding responsible of fice by the slow promotion in the museum world (as to academic tenure, Margaret Mead's rise was not meteoric; Associate Curator in 1942, Curator only in 1964). Others, again, prefer museum appointments for the freedom they give.

The interesting questions which Cassidy never attempts to broach are counterfactual conditionals about the interplay of sex, personality and culture, the very theme of Mead's life work. How much did she choose to be an outsider, how much was the choice a response to the opportunity structure she found herself facing - it is impossible to say. Yet, a man who showed such an early brilliance and energy would have been sought by major institutions which would have forced the conflict of ambition and independence to be played within supporting structures eminently able to bestow rich rewards on their favourites. Margaret Mead remained an individualist, she resisted capture by any institution and she exerted influence from outside the Establishment.

From her attic in New York Mead made a field trip of six months with her second husband, Reo Fortune, and published Growing Up in New Guinea in 1930. The path of research for the next ten years had been set. It was to show the malleability of human personality, the strength of cultural pressures to mould what are assumed in any one civilization to be personality traits indefeasibly linked to physical sex. The comparison of adolescence in Samoa and Manu'a was followed by comparison of three societies in New Guinea: the Arapesh, whose culture shows practically no differences in temperament between men and women, both being equally gentle and unaggressive; the Mundugumor, both sexes equally violent and ruthless; and the Tchambuli, a society where the men were artists and ran the ceremonies while the women were the real producers and entrepreneurial managers, the perfect complementary case to modern America.

One can pause to ask why she spent so little time in each of these societies. After all, this was the post-Malinowski era of long, intensive fieldwork. How, then, could
Cassidy not be sensitive to the import of his own remark: "After seven months she and Fortune had had their fill of the Arapesh". She felt she worked so much faster than anyone else; like a scientist, she chose a limited problem and could quickly tell whether she had collected enough evidence to settle the answer. Margaret Mead often complained that the British anthropologists were unappreciative of her achievements. This hurry-hurry, singleissue style of field work explains a significant difference between herself and her

\section{IMAGE \\ UNAVAILABLE FOR COPYRIGHT REASONS}

Margaret Mead in the late 1920s, after her return from Samoa.

British contemporaries - compare Audrey Richards, who wrote large monographs with impressive documentation and analysis on one tribe alone, and trained her students to keep going back and amplifying the results.

After her third marriage she went to two new field areas, Iatmul and Bali between 1936 and 1939. At this stage she had become interested in the techniques of ethnography, and the use of photography and film. In the 1930s she was one of the founders of the culture-personality movement in anthropology and was becoming very interested in national culture, but $\mathrm{Kar}$ diner and Dubois did the more important work in the first and Benedict in the second. She was there at the beginning of many intellectual movements but did not stay with them. One suspects that the demands of the mass media were beginning 
to pose an effective counter-attraction to obscure scientific study.

By the outbreak of the war Mead was a very famous anthropologist. New challenges were put to her. As executive secretary for the National Research Council she edited the Report of the Committee on Food Habits (1941-1943), full of interesting ideas about methods of comparing food habits and ideas about the relation between nutrition, social class and ethnic traditions. She advised the United Nations army on its relations with foreign cultures; she became an authority on technology and economic development and made it her prime mission to bring emerging Third World countries into the twentieth century. A peculiarly personal mantle of international counsellor and interpreter of the world fell upon her shoulders. No one wearing it with such authority and confidence should complain of lack of academic recognition. Yet I would pay her the compliment of greatly wishing that she had stayed more patiently with the growth of the ideas she brought to birth. Nothing in economic anthropology had anticipated her study of economic structures in the Admiralty Islands. She was right in believing at the end of her life that nothing significant had been built upon her important work on food habits. The outstanding problems about the relation of personality and culture are still unsolved and no method has been determined for solving them. But in academic life you either need to have institutional support or to concern yourself with the nurture of your own brain children.

It is fair to wonder with whom Mead should be compared. Was she a latter-day Marie Stopes? No, even their shared vilification as corruptors of morals does not put them on a par; Mead was less onetrack. What about contemporaries? Was she a great philanthropic writer? Dorothy Day is a giant name for an editor and committed social reformer, worthy for the comparison, but Mead's concerns were more dispersed. What about helping the Third World? Margery Perham, born in 1895 , achieved much on behalf of the constitution framers of emerging independent Africa? Certainly, I doubt that any of them would have envied Mead the international popular acclaim that she earned.

This biography pays scant attention to her anthropological work. It is clearly meant to be a friendly report. But it is not helpful to her academic reputation, now under attack by Derek Freeman (see p.758), to present her as a fabulous media star. Would Danny Kaye rather be remembered by his friends as a great comedian or as a great philanthropist? Margaret Mead herself cherished her academic standing, but this volume does nothing for such concerns.

Mary Douglas is Avalon Professor of the Humanities at Northwestern University, Illinois.

\section{Advancing by stealth}

June Goodfield

Women Scientists in America: Struggles

and Strategies to 1940.

By Margaret W. Rossiter.

Johns Hopkins University Press: 1983.

Pp.438. \$27.50, £22.

THERE are certain intriguing resemblances between the practice of science and the study of history: the more we observe, the more we recognize how much still remains to be discovered. Moreover what we actually see is strongly influenced by the questions we bring to our observations. Thus we can by-pass a great deal that may actually be very significant.

As directions in research become first fashionable, then hallowed, other aspects of a discipline may dwindle to near invisibility. It takes a Braudel, with his sweeping studies on the Mediterranean World, or a Ladurie in Montaillou and Love, Death and Money in The Pays d'Oc, to recreate lost lives and reveal the sheer dimension and complexity of the tapestry of history. Such was the majesty of their scholarship, and such the vision of their disciplined imagination, that the works of these pioneers forced those with minds not irrevocably closed to look with fresh eyes on old fields of study.

While it cannot be said that Margaret Rossiter is a Braudel or a Ladurie, her new book nevertheless achieves similar ends and is a seminal work of rich scholarly detail. It may not transform the history of science, but those who ignore its implications will be intellectually impoverished. Not too long ago many people believed that Marie Curie was the first - if not the only - woman scientist. The sixteen-volume Dictionary of Scientific Biography, edited by Charles Gillispie, did something to improve the situation but nothing like enough. Dr Marilyn Ogilvie's labour of love - lasting over a decade - which has culminated in a Dictionary and Biography of Women Scientists from Antiquity to 1910 will, when it finally sees the light of publication day, open our eyes still further. Now with Women Scientists in America Margaret Rossiter reveals that for well over a century "women have been an integral part of the scientific community" yet "for a variety of reasons" most of these women scientists bordered on the "invisible".

Once she had overcome the initial "stumbling block of locating material, through several years of detective work" the full wealth of the vein she was mining became apparent. The quantity of material discovered was enormous; once mastered, rich and deep analyses could be and were, undertaken. Thus Rossiter's account is not one whose only conceptual threads are those of feminist rhetoric. There is nothing simplistic here: she has given us a sophisticated analysis of a complicated situation, encapsulated in the following phrase: "It is the history of an occupational group whose status had risen and fallen over time as the women's role responded to external events and pressures"'. What Margaret Rossiter does so well is to explicate her story in those terms, backed by an abundance of empirical material, in quantity that would satisfy the most Baconian of scientists.

Beginning in the nineteenth century with the "entering wedge" provided by the women's colleges, we see the quiet infiltration of women into science, a movement that turned out to be unexpected, unintended and at certain times unwelcome. It is fascinating to notice that, at a time when science had a lowly status in Britain's institutes of learning, the Women's Colleges of America took pains to emphasize the extent of science in their curricula offerings, showing a slant undreamt of by C.P. Snow. For the emphasis placed on science "reassured the parents of the high moral character and religious values taught. (Literature, especially novels, were, by contrast, quite suspect.)"'. Given this difference in educational history, surely no one would ever have predicted that Britain would produce the first scientist ever to be a Prime Minister and a woman at that!

The ends which were ultimately achieved were far from being those for which the new ventures were launched. What began as a movement to educate women so that they would, in turn, produce more enlightened sons, ended with a group of highly motivated, qualified and often quite remarkable people having no place to go except back to where they came from - the women's colleges. This, rather than any inherent intellectual limitation, explains why few of these women scientists did research - though there were notable exceptions. That this situation, and its corollary, persisted for well over one hundred years is confirmed in Evelyn Keller's forthcoming biography of Barbara McClintock. McClintock's work in bacterial genetics was so brilliant that Joshua Lederberg, in the 1950s, once described her as either "mad or a genius", but she was forced to do her research on the fringes of academia. For she refused to relinquish her calling, even though appropriate positions in academic institutions were never forthcoming; nor would she abandon her lodestar and fall back into teaching science in a women's college.

Rossiter clearly displays the causes and

\section{Gentlemen of Science}

Oxford University Press have recently issued a paperback edition of Jack Morrell and Arnold Thackray's Gentlemen of Science: Early Years of the British Association for the Advancement of Science. In his review of the original edition (Nature 294, 19; 1981) Robert Fox spoke of the book as bristling "with challenging interpretations". Price of the paperback is $£ 7.95$. 